\title{
THE EFFECT OF FARTLEX AND EXTENSIVE INTERVAL TRAINING METHOD TOWARD THE FOOTBALL REFEREES SPEED ENDURANCE IN PADANG
}

\author{
Kamal Firdaus \\ Padang State University, Komp. Parupuk Raya B.36 Tabing Padang West Sumatera 25171 \\ Dr.Kamalfirdaus.mkes.aifo@gmail.com
}

\begin{abstract}
:
Many referees fail in following the physical capability test. The failure is caused by the low rate of physical fitness of the referees themselves. One of the factors that cause this condition is the physical training method. This research was aimed at knowing the effectiveness of the interval ekstensif training method and fartlek training method on the referees' speed endurance. This research was a quantitative study and employed a quasi experimental design. The population of this research was 75 people $=37$ had C3 licence, 13 people had C2 licence, 24 people had C1 licence and 1 person had FIFA licence. The sample was taken based on pumosive sampling technique in which 20 referees were chosen. The technique of data collection was test and the instrument used was the physical capabilities test $20 \times 150$ meters. Finally the data was analyzed by using $t$ test. The data analysis indicated that: The interval training method could improve speed endurance capabilities 20x150 meters with 21,75>2,26 (Mean pretest 30,86 and posttest 29,12 second). The fartlek training method could improve speed endurance capabilities 20x150 meters with 7,89 >2,26 (Mean pretest 30,88 and postest 30,17 second). There was a significant difference between the interval ekstensif training method and fartlek training method on speed endurance capabilities $20 \times 150$ metres with $3,28>2,101$. Based on the data above, it could be concluded that both training methods could improve the physical abilities of 20x150 meters; the interval ekstensive methods contributed a better influence than the fartlek methods. Furthermore it is suggested that all football referees use the interval ekstensive method and fartlek to improve the speed endurance capabilities of 20x150 meters.
\end{abstract}

\section{Academic Discipline And Sub-Disciplines}

Sport Education

\section{SUBJECT CLASSIFICATION}

Natural and Social

\section{Council for Innovative Research}

Peer Review Research Publishing System

\section{Journal: Journal of Social Sciences Research}

Vol. 9, No.1

jssreditor.cir@gmail.com

www.jssronline.com 


\section{ISSN 2321-1091}

\section{INTRODUCTION}

Sport is an activity needed by every people. Through sport, a person will obtain physical fitness, wellness thinking and achievement in the working field so it may increase their working productivity. In other side, sport can be one of competition to show an accomplishment. It is formed to maintain the achievements of individual, group or country.

Every sport branch was headed by a referee such as football. Football is one of the popular sports in the Indonesian's society. Many people like to watch and play the match not only in the city area but also the rural area. The players are not only adults but also kids. There are various reasons why they love to play football like spending the free time, exercising and looking for an achievement. This creates many football clubs and communities in the school area, training centre and others. The influence can be seen both in the city and rural area. The factors which cause this phenomenon are trainers, facilities, human resources like athletes or players and especially the referees.

According to Sumpeno and friends (2010:7) referee in a football match is a person who highly responsible to lead the match. The referee plays important role especially in a sport which leads to an accomplishment although he is not the only one to determine the result of the match. There are many factors that affect the result such as players, trainers, field, and supporters. Federation International Football Asosiation (FIFA, 2010:30) reveals that " every football match is headed by a referee with absolute authority to enforce the rules of the match where he is assigned to work". To become a referee, a person should fulfill the requirements which settled by PSSI.

Suryanto (2010) explains that the formal criteria to be a referee has been determined and established by PSSI or the legal sports organization such as educational certificates, physical condition (at least pass the cooper test), and particular experience.

A referee is expected to be able to run his functions well and proper by highly appreciated justice and responsibility in a particular match. This work is not easy. There are many difficulties can be found in the field. The difficulties may be faced because of disability in managing the match and other external factors.

The referee who is assigned to lead a particular match should master the rule of the game and have a good physical condition. By having a good physical condition, it may help him can stay close to the field and observe what happens during the match. In line with Zein (2009:2), the duty of a referee is to do and integrate the laws of the game and this is the reason why he is in the field. His duty is to uphold and interpret the laws of the game so it can guarantee that the game is going on fair, reasonable and competitive condition. Without having a good physical condition, a referee will find difficulties to do the work as the justificatory in the field. Muhammad Zein in Yendra (2011:3) explains that a referee without a good physical condition may not be able to lead the game properly and he never can stay close to the match means the ball. This is the reason why FIFA, AFC, and PSSI always conduct Fitness Test toward the referee and referee assistant before leading a match.

The speed endurance ability of a referee is the capability of a referee to run faster in $20 \times 150$ metre based on the time that is assigned by FIFA/AFC/PSSI. Running in the distance 150 metre needs 30 seconds in time. The time to have rest and break is 45 seconds.

Referring to the football referees of Padang city, some mistakes in decision making are often found. Based on opinion of some audiences, it is seen that the referee stays far from the ball. Therefore, it is difficult to see the violation. It brin gs out the protests from the players and the audience. This is caused by the weaknesses in physical condition of referee committee in Padang city. According to the Head of Referee Committee in Padang city, Yendra, the physical condition of football referees in Padang city seems decreasing which can be seen from the refreshment in several months ago.

The factors which cause the problem have not been known yet. Some factors which is presumed affect the running 20x150 meter from internal and external side are as follow: (a) physical condition, (b) motivation, (c) facilities, (d) training method (e) training frequency. In addition, the training which is given to the referee seems monotonous and less variation. Another factor is incomplete facilities, unclear instruction, leg, speed reaction and speed endurance. Thus, this causes the low motivation in training.

To achieve the optimum vision, it is important to examine the supporting factors combined with the scientific principles. The type of training method used may also affect the ability of referee running like extensive internal method and fartlek method. Both of these methods are beneficial to increase the endurance. The extensive internal method is an exercise to increase the aerobic endurance ability with shorter break time and faster in speed. This training may increase the endurance of referee to lead the 90 minutes match. The fartlek method is an endurance training system to build, return and keep somebody's physical condition where the changing of running speed is adapted to the athlete personal need or in other word the athlete detemine the referee's running speed.

Some elements of physical ability in football referees like endurance, speed endurance, explosion power, reaction speed, speed, and agility can be improved if the trainer understands every parts of the condition. Those elements can be seen when the referee leads the match in the field during $2 \times 45$ minutes, such as the referee should stand 10 meter close to the ball, and the referee should run to place where the violation happens. Throughout this method, the referee should concentrate to a particular aspect of condition and skill. The sport founder and coach create the training methods in order to develop the 20x150 meter running achievement. It is hoped that this research may inform the ideal train ing process to increase the physical ability of a referee. 


\section{METHOD}

The type of method which is suitable for this research is Quasy Experiment. Irawan (1999:68) reveals that "experiment in the social science is often clustered as "quasy". It means that the controlling proces toward the variables cannot be done strictly like in the exact sciences (without using the human unsur as the research object)". The independent variables of this reseach is the extensive internal method and fartlek method while the dependent variable is the speed endurance ability of football referee in Padang city.

The reserach was done in Haji Agus Salim Stadion Groundsman Padang and Football Field of UNP Sport Faculty. The reaseach was done during 2 months started from September till October 2014. While, the observation was done three times in a week every Sunday, Wednesday and Friday from 07.00 every Sunday morning and 4.30 every Wednesday and Friday afternoon. Before the treatment was given, the pretest was firstly done followed by posttest at the end of the treatment.

The population of this research is the football referee in Padang City who have C3, C2, C1 and FIFA certificates which are still active until the year of 2014. The total number of referee as the research population is 75 people.

The sampling technique of this research was purposive sampling technique where the particular research sample matched with the requirements (attitudes, characteristics, criterias) sample. Based on some consideration in obtaining the sample, the sample of this research was the referees who have the CII and CIII active certificates and the total number of the sample is 20 people.

The measuring process toward the speed endurance ability test of the referee was running test in $20 \times 150$ meter which is done based on the FIFA/AFC/PSSI requirement. In this case, PSSI determine the finishing time to accomplish 150 meter distance is 30 seconds with break in walking within 50 meter during 45 second. When entering the finishing line, the time would be recorded. Then, the average total time was counted. From the result of trial results, the realiability was obtained 0.61 and the validity was 0.63 . The conclution of this test is that the measuring instrument of running $20 \times 150$ meter can be used to measure the speed endurance ability of football referee.

\section{RESEARCH FINDING AND DISCUSSION}

\section{The extensive interval training method Increase The Speed Endurance Ability of Football Referees Running in 20x150 meter}

It was seen that the $t_{\text {calculation }} 21,75>t_{\text {tabel }} 2,26$. It means the extensive interval training method has an effect toward the speed endurance of football referee running in 20x150 meter. The preliminary data shows that the average time on the pre testis 30.86 second with SD 0.70 , while in the post test is 29.12 seconds with SD 0.628 . it means there is a significant improvement of extensive interval training toward the speed endurance of football referee in the amount of 1.74 seconds.

According to Syafruddin (1999:90) the characteristics of extensive internal method is the medium intensity load around $60 \%-80 \%$, the total or volume of high load and the total of repetition around $20-30$ times per series, and the training effect in improving endurance. Based on the theoretical review, Kosasih (1993:107) explains some factors which must be fulfilled in arranging the training interval method such as "(a) the length of the training (b) repetition (c) training intensity (d) recovery internal in every training repetition". The improvement of physical ability in running $20 \times 150$ meter is caused by the appropriate arrangement of the training program in which to improve the capability of heart, lungs, blood circulation and breathing.

In general, the purpose the physical test $20 \times 150$ meter is to measure the speed endurance owned by the football referee. Physiologically, speed endurance closely relates to the capability of hearts and lungs in consuming oxygen maximally. In this case, this training program of course should look forward to improving the hearts, lungs and blood pressure endurance. The interval training which is done repeatedly with varies distance will improve the speed endurance ability.

One characteristic of endurance training is the use of energy system which comes from Aerob; the source of the energy used from oxygen. The interval training uses more oxygen as the energy source so it can add the amount of oxygen in the lungs. With the vast amount of oxygen contained in the lungs, it means that the body is able to deliver more power to the contracting muscles. Then, the muscles are able to work in a long time. In addition, one positive effect of the amount of oxygen in the body is to delay the occurrence of fatigue due to the lack of oxygen in the muscles. This means that the referee has the effective circulatory and respiratory systems. Thus, they can follow the physical test of $20 \times 150$ meters well. On the other hand, extensive interval training method can be programmed and controlled well. It has similarities with the referee speed and endurance test running in 20x150 meters. In this case, the physiological speed endurance test of referee is running $20 \times 150$ meters. Hence, when a referee always has an extensive interval training program, it will allow the referee to pass the referee speed endurance test.

By running this extensive internal training, referees can improve the speed endurance ability. Thus, they can pass the test of the referee physical condition running $20 \times 150$ meters. This test is always held by the PSSI for the referee C1 in the selection of the assignment of referees in the Asprov National League. For the referee who owned C1 and C2 certificates, PSSI assigns them in the Liga areas such as the regional level archipelago league, the youth league and all PSSI official competition in particular area. This test was also performed at the level of PSSI Association at the County and City particularly in the legal selection of official referee assignment in a city or for someone who wants to be a referee, the test can also be used. If a referee is not able to pass the endurance speed test, the referee will not work for a year both at 
national and regional level. For someone who wants to be the referee and cannot pass this test, a test must be repeated again until the specified time. Hence, a referee must be able to pass the speed endurance test of $20 \times 150$ meters.

The findings explain that the extensive interval training can improve the referee speed endurance. By running the extensive interval training program in preparation for the selection of national or regional referee, a referee will be able to pass the test. in addition, they are always ready for the referee selection or to raise the referee license to a higher level. The extensive interval training is suggested to run by a referee.

\section{Fartlek Training Method Improve the Speed Endurance Ability of Football Referees Running in 20x150 meter}

The preliminary data of physical ability of running $20 \times 150$ meter which is trained with fartlek method shows that the pre test average score is 30.88 second while the final data shows that the average post test is 30.17 second. It means there is an improvement of physical ability in the amount of 0.71 second. After the data analysis is done, the data is obtained with $t_{\text {calculation }} 7,89>t_{\text {tabel }} 2,26$ (tabel 14). This figures that there is an improvement in the speed endurance ability of running $20 \times 150$ meter trained by fartlek training method

According to Syahara (2008:18), fartlek or playing with the speed is a method developed by runners in Skandinavia and Germany in the year of 1920-1930. The word "fartlek" can be interpreted as plaring with speed. This exercise is suitable for muscular endurance and cardiovascular endurance. Fartlek is a development method in which the changes of speed endurance while running was tailored to the needs of individual athletes, or in other words, athletes determine their own speed. Irrawaddy (2011: 46) said that the main characteristics of the fartlek method is the change of the performance intensity which is done at any time without planned and carried out continuously in a set time. When doing the Fartlek or playing with the speed, , the referee provide input in determining changes in the uninterrupted exercises, like a form of short-distance portions. Those are performed with high intensity performance. The sprints are done without pre-planned and solely based on feelings and subjective assessment of the referee. The use of this method is usually very special - but it is conducted entirely in the preparation phase. This is a variation which can give another feel in a running practice to achieve the maximum durability. Thus, fartlek training method affects the physical abilities in following the referees selection of $20 \times 150$ meters.

If a referee runs the fartlek exercise, it can improve the speed endurance ability so the referee can pass the physical condition test of running 20×150 meter. The test is regularly held by PSSI for C1 referee before assigning to work in Asprov National League. Next, A test is also done for C1 and C2 referees before assigning them to work in Local Level Nusantara League, Youth League, and all legal competitions held by PSSI in a particular area. This test was also performed at the level of PSSI Association at the County and City particularly in the legal selection of official referee assignment in a city or for someone who wants to be a referee, the test can also be used. If a referee is not able to pass the endurance speed test, the referee will not work for a year both at national and regional level. For someone who wants to be the referee and cannot pass this test, a test must be repeated again until the specified time. Hence, a referee must be able to pass the speed endurance test of 20x150 meters. The finding explains that though fartlek training, a referee may improve his speed endurance ability. The fartlek training is similar to the condition when the referee led a particular match because the referee should have ability to run fast, constant and slow even when they are walking. In this case, the referee must be able to adjust to the four kinds of times in the football game. As Emral (2014: 89) said that a football athlete must know the four-time. It is the time when the ball is on the opponent, the ball is in our time, the ball is in a time shift from the defender to the attacker and the ball is on the switching time from the attacker to the defender. In this course, each soccer player should know about the times. A referee should be able to run fast when the displacement of the ball lies from the defender to the attacker. It usually called as diagonal movement in umpiring the match. The case is happened especially when the ball is close to the goal. A referee must be able to stand in line of sixteen so they can see the events in a box of sixteen and see the goal which is created. Sometimes in this case, the defender player of one team kicks the ball forward so the referee had to run to always get close to the ball. Therefore, a referee should have the ability to run fast and fartlek training is good for training them to be accustomed in running at the field.

\section{The Extensive Interval Method is better than Fartlek Method}

After giving the treatment through the two following methods, it shows that the extensive internal method is better than the fartlek training method toward the football referee speed endurance ability of running $20 \times 150$ meter in Padang city. It is seen that the extensive interval training method has difference score 1.74 second while the average score of fartlek training method is 0.71 second. Then, it also shows that $t_{\text {calculation }} 3,28>t_{\text {tabel }} 2,101$. Based on the mean of the different test results, the hypothesis that says there is a difference between the extensive internal methods with fartlek method toward the referee speed endurance ability of running $20 \times 150$ meter is proven. It means that Ho is rejected and the truthfulness of $\mathrm{Ha}$ is accepted because the $\mathrm{t}_{\text {calculation }}$ is bigger than $\mathrm{t}_{\text {tabel }}$.

The interval training method is one methods of physical training that focus on the arragement of working time and resting time while training. This break/rest time is needed for body to recharge the condition which has been tired. When the training is continued, body will give a resistance toward the tiredness of the previous training process. As a result, the fisiology adaption is happened inside the body. When the training load is ended, there is an improvement in the physical condition.

In other side, Fartlek is a form of physical training that uses some types of rapidity. Fartlek or playing with speed is form ed in short distance portions which are done with high performance intensity. The sprints are done without any planning and based on feeling and subjective assessment of the referee. The use of this method is usually very specific but it was whole 
done in the preparation phase for the physical maturity of the football referee. The football referee must be able to run quickly or slowly with this farlek method. Thus, he can improve his physical ability to run in a test of $20 \times 150$ meter as assigned by FIFA and PSSI. It means that the the fartlek method may increase the whole referee speed endurance in a short time. If the training program is designed based on the expected purpose, this training can increase the referee speedn endurance ability. Through the improvement of whole physical condition, it is believed that the referee is able to accomplish the physical ability test in running at $20 \times 150$ meter.

Based on the findings that have been raised, it can be concluded that the two methods give the influence to increase in football referee speed endurance. However, there are differences in the influence of extensive interval training methods and fartlek training methods toward the physical ability football referee to run in 20x150 meters. From the results of the research, it is proved that the extensive interval method is better than the fartlek method as it can be easily programmed and controlled well. In addition, it closely leds to the referee test of running in 20x150 meters. Then, those who are serious indirectly motivated by the target date in the practice. In contrast, fartlek method is difficult to control. Those who follo w the training are not forced maximally because the variation of speed in exercising is varied. On the other hand, it does not have the same characteristics to the speed endurance test of running in 20x150 meters. For those who are serious in the fartlek training need to have targets within the time which is taken in fartlek. However, fartlek training has a bit similarities with the match to lead on the field. The reason is because in leading the match, a referee should be able to sprint and run slowly or walking. It can be said than leading a match with fartlek method is playing around with the speed. By implementing a farlek training program well, it can additionally improve the referee speed endurance to run in the test of $20 \times 150$ meters. It will also familiarize the body movement while leading the match.

\section{CONCLUSION AND SUGGESTION}

Based on the hypothesis testing, there are some conclusion can be taken as follow;

1. The extensive interval training method can improve the speed endurance of $20 \times 150$ meters footb all referee in Padang.

2. The fartlek training method can improve the speed endurance of $20 \times 150$ meters football referee in Padang.

3. The extensive interval training method gives a greater influence than the fartlek training methods.

\section{SUGGESTION}

Based on the research findings and conclusions, the authors suggest the following ideas:

1. All football referees should perform exercises using the extensive interval and fartlek method to improve the endurance speed of $20 \times 150$ meters.

2. All football referees should do the physical exercise with a frequency of three times a week so that the level of physical fitness held always maintained.

3. The PSSI Executive Branch of Padang should conduct coaching for the physical condition of football referees through extensive interval training program to improve the endurance speed of $20 \times 150$ meters.

4. The Provincial Board (Pengprov) of PSSI in West Sumatra should always suggest all the referees to do physical exercise through extensive intervals and fartlek in order to improve the endurance speed of ${ }^{n n \ldots}{ }^{r} 0$ meters.

5. The Center Board of PSSI should arrange some form of extensive interval training and program in order to improve the physical ability of a referee in following the fitness test of $20 \times 150$ meters. It shoura be used as a refer ence by the PSSI, AFC and FIFA in determining the level of physical fitness held by the football referee.

6. FIFA, AFC and PSSI as the authorized football organization should maintain the test of $20 \times 150$ meters because it is still suitable for measuring the ability of endurance speed (speed endurance) owned by the referee.

\section{REFERENCES}

[1]. FIFA, (2011) Peraturan Permainan (Laws of the game), Jakarta : Bidang Sumber Daya PSSI

[2]. Hairy, Junusul. (2003). Daya Tahan Aerobik. Jakarta: Direktoral Jendral Olahraga Departemen Pendidikan Nasional

[3]. Irawadi, Hendri.( 2011). Kondisi Fisik. Padang: FIK

[4]. Irawan, Prasetya. (1999). Logika Prosedur Penelitian. Jakarta: Sekolah Tinggi Ilmu Administrasi - Lembanga Administrasi Negara.

[5]. Kosasih, Engkos. (1993). Olahraga, Teknik, \& Program Latihan. Jakarta: Akademika Pressindo

[6]. Lutan, Rusli. (2002). Menuju Sehat dan Bugar. Jakarta: Direktorat Jenderal Olahraga, Depdiknas.

[7]. Margono, S. (2003). Metodologi Penelitian. Jakarta. Rineka Cipta

[8]. PSSI, (2008). Peraturan Umum Pertandingan ; Jakarta

[9]. PSSI, (2008), Pedoman Dasar PSSI ; Jakarta

[10]. Syafruddin, (1999). Dasar-dasar Kepelatihan Olahraga. Padang ; FIK-UNP DIP Proyek Universitas Negeri Padang.

[11]. Syahara. (2009). Pertumbuhan dan Perkembangan Fisik \& Motorik. Padang: FIK UNP. 


\section{ISSN 2321-1091}

[12]. Yendra, (2012). "Pengaruh metode latihan interval dan sirkuit terhadap kemampuan lari $6 \times 40$ dan 20150 wasit pengcab PSSI Kota Padang". (Tesis Prodi Manajemen Pendidikan Olahraga PPS UNP). Padang: PASCASARJANA UNP.

[13]. Zein, Muhammad. (2009). Sepakbola Indonesia Bermain Dalam Aturan. Jakarta: Persatuan Sepakbola Seluruh Indonesia.

\section{CURICULUM VITAE}

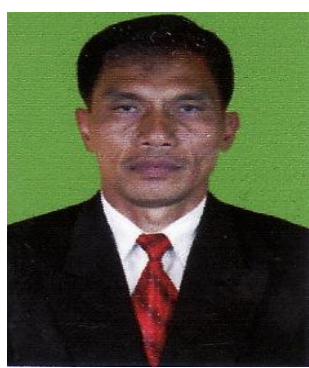

Firdaus Kamal, was born in Jambi November $12^{\text {th }}$, 1962. He was the second s on of Mr. H. Sutan Pameran (Am)and Mrs. Hj. El zas M. (fom Bukittinggi).

He married to Agus Nelly and had a child named Rahmat A Ażz Katialy, the student of Pembangunan UNP Senior High School.

He has finished her primary education in SD N 01 Bajubang Jambi in 1975, Junior High School in Bajubang Jambi in 1978, Senior High School in Bajubang Jambi in 1981, and Sport Science Faculty, Institute of Science Teacher and Education of Padang in 1985. He continued his master study to obtain Sport Science Magister Program in Airlangga University and finished in 1999 . He also continued his doctoral degree in 2009 on the Sport Education Study Program at Semarang University and accomplished in 2012.

In 1987, he was appointed to be the School Gym Teacher and in 1990, he moved to the Institute of Science Teacher and Education in Padang until now.

His scientific activities are Sport Science Technology (Scientific Papers, 1998), PB Pelti Instructor (Works hop, 1994), The Role of Secology, Psychology and Sports Business in Supporting the Improvement of Sports Performance (Symposium, 1997), International Tennis Federation Coaching Workshop (2000), Intersection Scientific Work of Science and Technology of Sports (Works hop, 2007).

Moreover, his scientific works or books are General Science of Sport (UPI Bandung, 2003), Sports Marketing (UPI Bandung, 2006), Sport Management (UPI Bandung, 2008). 